\title{
Bossnapping: Situating Repertoires of Industrial Action in National and Global Contexts
}

Publication details:

Modern \& Contemporary France, 20/2, pp. 185-201, May 2012

Published online 10 April 2012, doi 10.1080/09639489.2012.665577

http://www.tandfonline.com/doi/abs/10.1080/09639489.2012.665577

GRAEME HAYES

School of Languages \& Social Sciences, Aston University, UK

\section{Correspondence address:}

School of Languages \& Social Sciences, Aston University, Aston Triangle, Birmingham B4 7ET, UK

Email: g.a.hayes@aston.ac.uk

\begin{abstract}
French industrial relations were shaken in the spring of 2009 by a series of labour struggles which featured the forcible detention of company managers and threats to commit major acts of sabotage. In this article I focus on the first of these two types of action, placing industrial sequestration in the context of the pattern of collective negotiation processes in France, and comparing it with previous cycles of the same phenomenon, particularly in the post-1968 period. I argue that the current cycle of sequestrations needs to be understood as a response to the deterritorialisation processes of neo-liberal globalisation, and is the product of asymmetries of power between the fixity of labour and the fluidity of global capital. I conclude by arguing that sequestration is a public melodrama of protest which might point to the development of a resistant politics of corporeality in France, in common with struggles in other social and economic sectors.
\end{abstract}

\section{KEYWORDS}

Sequestration; Action Repertoires; Globalisation; Melodrama; Resistance. 


\section{Bossnapping: Situating Repertoires of Industrial Action in National and Global}

\section{Contexts}

The spring and summer of 2009 saw a number of remarkable events in French industrial relations. Workers threatened with factory closures or significant job losses forcibly detained company chief executives or plant or regional managers, for periods typically ranging from an hour (François-Henri Pinault, owner of FNAC and Conforama, held in his taxi in Paris in March 2009) to twenty-four hours. Companies hit by these actions include Sony France, 3M, Caterpillar, Faurecia, Scapa, Molex, and Servisair. But that was not all. In the last week of March 2009, workers at the Celanese chemicals factory in Pardies (Pyrénées-Atlantiques) started a 'relay' hunger strike following the decision of its American parent company to close down the factory, with the loss of 350 jobs; the following month, faced with a restructuring plan, four union representatives at the Madrange meat plant at Feytiat, near Limoges, did the same; and workers at German tyre manufacturer Continental's Clairoix plant, to be closed with the loss of 1100 jobs, destroyed the factory's reception post and ransacked the subprefecture in Compiègne. And as spring moved into summer, workers at JLG, New Fabris, and Nortel France went further, threatening to blow up their factories if their demands weren't met; in July, workers at SKF in Fontenay-le-Comte set fire to machinery; in August, employees at Serta's haulage hub just outside Rouen threatened to pour 8000 litres of dodecylphenol (a toxic fuel additive) into a tributary of the Seine, and workers at Chaffoteaux \& Maury in Ploufragan, near St Brieuc, occupied their factory and shut out the management, in protest at Ariston's decision to concentrate production in Italy; in December, workers at Hymer in Alsace started dismantling one camping-car per day in order to force their (German) head office to negotiate over its decision to close the factory. In April 2010, workers at Sodimatex in the Oise threatened to blow up their factory, and workers at PIP in the Var occupied and threatened to set fire to theirs, both scheduled for closure; and a new round of sequestrations started, with plant managers at Akers, Siemens, Sullair, Essex, and PTPM amongst those forcibly detained by their employees in the first few months of the year.

Perhaps not surprisingly, French and international media commentators have tended to see these incidents as both 'radical' and somehow intrinsically French, testament to a living national culture of protest and to the structure of social relations in France; 'Locking up managers is increasingly becoming a Gallic tradition' argued the Daily Mail; ' 'In a global downturn, every nation has deep gripes. But only the French have a wave of bossnappings', said Newsweek; ${ }^{2}$ 'Bossnapping or the threat of blowing up a factory is part of a theatricality 
which lies at the heart of French culture', claimed The Guardian. ${ }^{3}$ Many in France agreed, if mostly in more nuanced fashion: 'It's very typically French, caused by the nature of social dialogue in our country', according to management consultant Olivier Labarre; 'Abroad, there is practically no radical conflict like this', argued Guy Groux. ${ }^{5}$ The sequestration of company bosses was thus dominantly cast in media discourses within a narrative of continuity, typical of France's tradition of industrial relations: a culture characterised by weak mechanisms of collective bargaining, a lack of willingness on either side to seek compromise, and where concessions are generally only granted under the pressure of agitation (Adam \& Raynaud, 1978; Jacquier, 2008). This is, after all, not the first time that French workers have sequestered their bosses. In 1968, company managers were sequestered at, inter alia, Sud-Aviation in Nantes, Renault-Cléon, the Compagnie des piles industrielles in Elbeuf, and at the Kléber-Colombes factories at Elbeuf, Le Havre and Rouen; the form of action was by this time already familiar from the Popular Front, and the strikes of 1947. In the post-1968 period, sequestrations were for a time widespread (if occurring in only a very small proportion of labour conflicts); Dubois (1973, p.410, n.1) estimates, for example, that in 1971, there were 'probably fewer than a hundred' incidences of sequestration, mostly in plants belonging to major industrial firms with highly bureaucratised management structures (p.416).

Explanations of this phenomenon stressing continuity and their integration into a French pattern of industrial relations are thus persuasive. However, they generally do not explain why the sequestrations of managers happened now, at this time, in this way, with these demands, led by these groups, in these workplaces - frequently, as we shall see, multinational corporations with head offices outside France. They also typically overlook what is national, what is transnational, and what is international about their character. My initial aim here is to set out a typology of the current cycle of management sequestrations in France, and to set it against previous iterations, particularly the cycle of sequestrations in the years following 1968. I argue that the current cycle has much in common with the previous cycle, including its relatively spontaneous nature, and its pattern of institutionalisation. However, I also argue that a key difference is the short-term and conservative nature of the demands associated with sequestration in the current cycle, and its lack of integration within transformative industrial politics. Contextualising this within the dominant tenor of studies on the relationships between globalisation and social movement organisation, I argue in the final section, in the spirit of Burawoy's exhortation for us to 'capture what is experienced on the ground, the ways globalization attaches itself to everyday life' (2000, p.339), that the current 
cycle of sequestrations is a product of the dynamics of neo-liberal globalisation, which affects the meanings and forms of established movement action repertoires. The current cycle of sequestrations of company managers in France expresses, I will argue, a public melodrama of protest in the face of the unattainable mobility of transnational capital. It combines expressive and instrumental goals in a contestatory politics of presence.

\section{Typology: Linking Grievances and Action, Mediatisation and Diffusion}

Dubois defines a sequestration, in the context of a labour dispute, as 'the temporary and concerted detention of one or several members of a company's board or management, undertaken in a known place' (1973, p.410). The spring 2009 cycle of such actions began with the detention of the chief executive of Sony France, Serge Fouchet, and three other managers. The four were obliged by workers to spend the night of 12-13 March in Sony's Pontonx-sur-l'Adour factory, scheduled to close a month later as the company sought to invest in production elsewhere, notably in Slovakia. The executives were released once they had agreed to invest a further $€ 13$ million in an employee retraining programme. In the following weeks, there were a further seven major instances of sequestration of company managers, at Caterpillar, 3M, Molex, FM Logistic, Scapa, Faurecia and Servisair. Though other forms of action continued through the summer, sequestration tailed off in the second half of 2009, to return for a few more months in early 2010, followed by isolated examples in 2011. Table 1, below, sets out a comprehensive list:

Table 1: List of sequestrations since 2008 (public and private sectors)

\begin{tabular}{|l|l|l|l|l|}
\hline $\begin{array}{l}\text { Date } \\
(\mathrm{MM} / \mathrm{YY})\end{array}$ & Company & Nationality & Sector & Location \\
\hline $02 / 2008$ & BRS & UK & Automotive parts & Devecey (Doubs) \\
\hline $03 / 2008$ & Kléber-Michelin & France & Machine parts & $\begin{array}{l}\text { Toul (Meurthe-et- } \\
\text { Moselle) }\end{array}$ \\
\hline $03 / 2009$ & Sony France & Japan & Electronics & $\begin{array}{l}\text { Pontonx-sur- } \\
\text { l'Adour (Landes) }\end{array}$ \\
\hline $03 / 2009$ & 3M & USA & Telecommunications & Pithiviers (Loiret) \\
\hline $03 / 2009$ & Caterpillar & USA & $\begin{array}{l}\text { Construction and } \\
\text { mining equipment }\end{array}$ & Grenoble (Isère) \\
\hline $04 / 2009$ & Molex & USA & Automotove parts & $\begin{array}{l}\text { Villemur-sur-Tarn } \\
\text { (Haute-Garonne) }\end{array}$ \\
\hline $04 / 2009$ & FM Logistic & France & Transport logistics & Woippy (Moselle) \\
\hline $04 / 2009$ & Scapa & UK & $\begin{array}{l}\text { Adhesive films and } \\
\text { tapes }\end{array}$ & $\begin{array}{l}\text { Bellegarde-sur- } \\
\text { Valserine (Ain) }\end{array}$ \\
\hline
\end{tabular}




\begin{tabular}{|c|c|c|c|c|}
\hline $04 / 2009$ & Faurecia & France & Automotive parts & $\begin{array}{l}\text { Brières-les-Scellés } \\
\text { (Essonne) }\end{array}$ \\
\hline $04 / 2009$ & $\begin{array}{l}\text { Université de } \\
\text { Rennes } 2\end{array}$ & France & Higher education & $\begin{array}{l}\text { Rennes (Ile et } \\
\text { Vilaine) }\end{array}$ \\
\hline $04 / 2009$ & $\begin{array}{l}\text { Université } \\
\text { d’Orléans }\end{array}$ & France & Higher education & Orléans (Loiret) \\
\hline $04 / 2009$ & $\begin{array}{l}\text { CROUS Port- } \\
\text { Royal }\end{array}$ & France & $\begin{array}{l}\text { Higher education } \\
\text { services }\end{array}$ & Paris \\
\hline $07 / 2009$ & Servisair Cargo & France & $\begin{array}{l}\text { Aviation ground } \\
\text { services }\end{array}$ & Roissy (Essonne) \\
\hline $07 / 2009$ & Michelin & France & Automotive (tyres) & $\begin{array}{l}\text { Montceau-les- } \\
\text { Mines (Saône-et- } \\
\text { Loire) }\end{array}$ \\
\hline $10 / 2009$ & $\begin{array}{l}\text { Rohm and Hass } \\
\text { (Dow Chemical) }\end{array}$ & USA & Chemicals & Semoy (Loiret) \\
\hline $01 / 2010$ & FCI & France & Boiler manufacture & $\begin{array}{l}\text { Lons-le-Saunier } \\
\text { (Jura) }\end{array}$ \\
\hline $01 / 2010$ & Akers & Sweden & Metallurgy & Fraisse (Loire) \\
\hline $02 / 2010$ & Pier Import & France & Retail & $\begin{array}{l}\text { Villepinte (Seine } \\
\text { Saint-Denis) }\end{array}$ \\
\hline $02 / 2010$ & Helio Corbeil & France & Printing & $\begin{array}{l}\text { Corbeil-Essonnes } \\
\text { (Essonne) }\end{array}$ \\
\hline $02 / 2010$ & Renolift & France & $\begin{array}{l}\text { Lift construction and } \\
\text { renovation }\end{array}$ & Meyzieu (Rhône) \\
\hline $03 / 2010$ & Siemens & Germany & Electronics & $\begin{array}{l}\text { Saint-Chamond } \\
\text { (Loire) }\end{array}$ \\
\hline $03 / 2010$ & $\begin{array}{l}\text { Sullair (United } \\
\text { Technologies } \\
\text { Corporation) }\end{array}$ & USA & Pneumatic parts & Montbrison (Loire) \\
\hline 03/2010 & $\begin{array}{l}\text { Assistance } \\
\text { publique- } \\
\text { Hôpitaux de Paris }\end{array}$ & France & Public health service & $\begin{array}{l}\text { Créteil (Val-de- } \\
\text { Marne), Ivry-sur- } \\
\text { Seine (Val-de- } \\
\text { Marne), Sevran } \\
\text { (Seine Saint-Denis), } \\
\text { Bobigny (Seine- } \\
\text { Saint-Denis) }\end{array}$ \\
\hline $04 / 2010$ & $\begin{array}{l}\text { Essex (LS Cable } \\
\text { (LG)) }\end{array}$ & S Korea & Copper wire & $\begin{array}{l}\text { Mâcon (Saône-et- } \\
\text { Loire) }\end{array}$ \\
\hline 04/2010 & $\begin{array}{l}\text { Caisse d'épargne } \\
\text { Ile-de-France }\end{array}$ & France & Financial services & Paris \\
\hline $04 / 2010$ & $\begin{array}{l}\text { Société nouvelle } \\
\text { de panification }\end{array}$ & France & Bread, pastry & Couffouleux (Tarn) \\
\hline $04 / 2010$ & PTPM (Trèves) & France & Materials (automobile) & Aÿ (Marne) \\
\hline $05 / 2010$ & EAK & France & Airbags, seatbelts & $\begin{array}{l}\text { Valentigney } \\
\text { (Doubs) }\end{array}$ \\
\hline $05 / 2010$ & $\begin{array}{l}\text { Vigimark } \\
\text { Surveillance } \\
\end{array}$ & France & Security services & Meulan (Yvelines) \\
\hline $07 / 2010$ & $\begin{array}{l}\text { Jacob Delofon } \\
\text { (Kohler France) }\end{array}$ & France & Sanitation & $\begin{array}{l}\text { Brive-la-Gaillarde } \\
\text { (Corrèze) }\end{array}$ \\
\hline
\end{tabular}




\begin{tabular}{|l|l|l|l|l|}
\hline 06/2011 & $\begin{array}{l}\text { MBF } \\
\text { Technologies } \\
\text { (Arche) }\end{array}$ & France & Automotive & Saint-Claude (Jura) \\
\hline 09/2011 & $\begin{array}{l}\text { Constellium } \\
\text { (Apollo/ Rio } \\
\text { Tinto / FSI) }\end{array}$ & France & Aluminium & Ham (Somme) \\
\hline
\end{tabular}

These episodes have a number of typical features. Foremost, they were short-lived and did not involve physical assault or harassment beyond the obvious fact of involuntary detention; sequestered managers were physically well treated, being provided with food, water, camp beds, maintaining external communications access, and in some cases continuing to enjoy the freedom to move around (if not leave) the premises. In all cases, sequestration followed the announcement of a plan de sauvegarde de l'emploi, or plan social, seeking to lay off significant percentages of the workforce in a given plant, and frequently took place following the meeting of the comité d'entreprise. In nearly all cases, these were private sector, blue collar, industrial workers, often subcontractors in sectors bearing the brunt of the downturn, located in small towns with few other employment possibilities, in companies whose head office was outside France (Sony, Molex, Scapa, and so on). Most sequestrations lasted less than twenty-four hours; the longest to date, of the managing director and human resources manager of South Korean copper wire manufacturer Essex in April 2010, lasted three nights (about sixty hours). There have been no other incidents of the type of material violence in evidence in the actions of Continental workers in April 2009, nor have sequestrations been accompanied by threats of sabotage or deliberate environmental destruction, as at JLG, New Fabris, Nortel France, Serta, or (notoriously) Cellatex at Givet in the Ardennes, where workers released a quantity of sulphuric acid into the Meuse in July 2000 in protest against the closure of their factory (see Larose et al 2001). In this cycle of sequestrations, at no stage and in no instances have law enforcement officers intervened to free the detained company managers (in the Essex dispute, the Mâcon Tribunal de grande instance rejected an application by the company for the police to clear the site and free its two forcibly detained managers). In the private sector, there have been no subsequent arrests for sequestration, and with one exception (at Molex), there have been no effective legal procedures opened against those responsible for sequestering their managers. ${ }^{6}$

Perhaps the most straightforward explanation of why these events have taken place thus lies in the objective deterioration of economic conditions in the wake of the subprime 
global financial crisis of 2008, leading to factory closures and large-scale redundancies. In 2009, 2,242 plans de sauvegarde de l'emploi (a legal obligation for all companies of 50 or more staff laying off ten or more employees) were announced, as against 1061 in 2008 and 957 in 2007. ${ }^{7}$ Data from the DARES records a startling decline in employment in France in the final trimester of 2008 and the first two trimesters of 2009, producing a net loss of 145,000 jobs in 2008 and 255,000 jobs in 2009 (as opposed to a net growth of 348,000 in 2007). 168,000 jobs were lost in industrial manufacturing alone in 2009. At its most intense, 143,000 jobs were lost across the economy in the first four months of 2009. Job losses in a single year were the highest since records were kept in 1954; the overall unemployment rate rose by 700,000 to 2.7 million claimants between the start of 2008 and the end of 2009. At $9.9 \%$ of the total working population, the unemployment rate at the end of 2009 was the highest since 1999 (DARES 2010).

However, the objective identification of acute grievances is not in itself a sufficient factor for explaining either the form or the incidence of protest group mobilisation. In order to understand their rapid spread, we also need to account for the presence of a generalised strong cultural acceptance of direct action in labour issues, and of previous iterations of the specific action of sequestering company bosses as part of the established social movement repertoire; the transferability and reproducibility of action; effective diffusion processes; the absence of repression on the part of the public authorities; and the evident effectiveness of action. Indeed, such was the effectiveness and resonance of action that it was quickly capable of spreading beyond its core typology, becoming both radicalised (moving to threatened sabotage) and normalised within its cycle, mutating and remaining prevalent as an underlying strategy, maintaining some of its effectiveness but enjoying decreasing media potency. One way of explaining this is to look at the design and cultural value of the action itself. Sequestration is 'modular' (to borrow Tarrow’s terminology (1998, pp.29-42): given similarity of background structural contexts, it is portable, transferable, and generalisable, in this case requiring minimal financial and organisational resources, and running few risks of professional or penal sanction; and it forms a long established part of what Tilly identifies as the national repertoire of contention, or the 'set of means which is effectively available to a given set of people' (1984, p.307).

Together, these factors point to the likelihood that the action would spread; but they do not explain how it spread. Three broad, and often rival, processes predominate in the study of protest diffusion (Kolins Givan, Roberts \& Soule, 2010, pp.1-3). The first two predominantly stress spontaneity, with diffusion brought about either by global 
communications (mediatisation) or through the activation of social networks; the third privileges the presence of organisations as the key conduit for the spread of specific action forms, providing the resources and capacity for orchestrated emulation. The first-hand accounts of the actors involved tend to point to the former as the more likely explanation; indeed, the evidence points to sequestration as improvised and relatively spontaneous incidences of action, rather than a coordinated or nationalised movement or campaign. Spontaneity, indeed, is a recurring motif of action: to take one example, according to Denis Parise, the CGT secretary of Molex's workers' committee, of the decision to sequester the managing director and director of human resources respectively of Molex Automotive's French operation, 'Nothing was premeditated, the workers saw that the [management delegation] weren't interested in their demands, and decided, by consensus, spontaneously, to detain the bosses on the site'.

Parise's claim is relatively typical of the cycle as a whole. However, two other factors also recur. The first is that sequestrations have been opportunistic and 'bottom-up' in their organisation and have received little support from the main union federations, even where links have been forged between plants engaging in these types of direct action. A demonstration in Châtellerault (Vienne) organised in support of the New Fabris workers, for instance, welcomed delegations from other factories experiencing similar difficulties and developing similar direct action responses across France - Aubade, Continental, Molex, and so on - but none from national union federations, and mobilised only a thousand or so demonstrators. ${ }^{9}$

The second point is that mediatisation was consistently a central goal of the action. Sequestration and the media attention it brought was typically a means either to accelerate or restart stalled negotiations on redundancy and retraining packages, and to force companies to improve the terms of the offer on the table. 'We've been nice for months and months, but now it's time for management and the government to stop taking us for idiots' is how the CGT representative on the comité d'entreprise explained the decision to sequester at PTPM in April 2010. ${ }^{10}$ In nearly all cases, the tactic was highly effective: sequestering was rarely anything other than highly mediatised, in France and abroad, across print, broadcast and electronic platforms, and enabled workers to gain much improved terms. 'The first night, Europe 1 and Reuters were there. The next day, ten satellite trucks and thirty journalists. And they were backing us. We wanted to damage 3M's brand reputation so that they would come back to the negotiating table. From that point of view, our tactic worked', as one worker involved in the Pithiviers action put it (cited in Ducros \& Guérin, 2010, p.19). At Nortel, the 
reasoning was similar: mediatisation is important because 'Ernst \& Young can't possibly be enjoying the publicity it's currently getting' ${ }^{11}$

This is not to say that organisations were not important. The spectacular nature of the incidents - illegal activity, adversarial relations, human drama, dynamic visuals, an encompassing narrative - doubtless explain their mediatisation; the decline of sequestration as an action form, first replaced by more spectacular and alarming forms of industrial action, then re-appearing in a number of disputes in spring 2010 but attracting considerably less mediatisation, is consonant with a variation of the media 'issue-attention cycle' identified by Downs (1972). Yet the availability of local spokespersons and their integration into organised labour movements and networks meant that, in media terms, sequestrations achieved the considerable feat of (to play on Gamson's phrase) both talking loudly and carrying a big stick (see Gamson, 1990, p.87). Sectorally, sequestration is thus one available response to the peculiar structural arrangement of French labour relations: low unionisation and the difficulty of national grievance aggregation make strikes relatively rare in the private sector; alternate forms of action are perhaps more important than strikes in any case given the prospect of factory closure; union presence provides knowledge, organisational resources and legitimacy and, crucially, the capacity to contain and channel action back towards institutionalised mediation and problem-solving. Indeed, as Béroud underlines, despite the media focus on 'radical' actions, the long-term data points towards the pacification and diversification, rather than radicalisation, of the terms of industrial conflict in France. Moreover, 'radical' actions should be understood relationally: rather than isolated 'explosions' of violence or confrontation, these are primarily media-oriented actions integrated into collective strategies, designed to bring institutional actors into play through the creation of an advantageous rapport de forces (Béroud, 2010, pp.3-4).

\section{Repertoire Change, and the Specificity of the 2009-10 Cycle}

Identifying the common features of these actions is clearly useful, but it has little explanatory value for understanding what might be different about this cycle of sequestrations , particularly compared to the post-1968 cycle. This section therefore compares the form and goals of sequestrations with previous iterations, arguing that though there is a formal continuity in sequestrations, there are nonetheless key observable differences, particularly concerning the goals of the current incidents. In the following section, I will go on to provide an explanation for this. 
In his work on industrial action in the 1970s, Dubois argues that there are two types of radical labour conflict: explosive radicalism, characterised by a 'lack of preparation and also frequently by being dependent upon action on the part of management in calling into question any previously acquired gain', its 'isolated nature within a particular strike', and its lack of integration into an 'overall radical strategy'; and planned radicalism, an offensive rather than defensive tactic, bringing together disputes, coordinating action from one plant to the next, which 'seeks not only to resolve the grievance but also to attain a more lasting change in employee/employer relations [...] by rejecting the accepted rules, it may go so far as to symbolise a different set of social relationships and another model of society' (1978, p.11). For Dubois, the sequestration of management in the post-1968 period in France was planned, a disavowal of the institutionalisation of conflict resolution and an attempt to produce change in the social system (1978, p.31). Industrial relations in this period were characterised by a decade of 'insubordination ouvrière' (Vigna, 2007), with widespread factory occupations and sequestrations set against a backdrop of high and (in the first half of the 1970s) increasing industrial employment, relatively strong unionisation (compared to current levels, at any rate), and shop-floor competition between a traditional left wedded to electoral victory and the discipline of class struggle, and a heteroclitic nouvelle gauche challenging bureaucratic statist solutions to social transformation. Factory occupations in particular functioned as a demonstration of organisational capacity within an ongoing construction of power relations, both between labour organisations (principally, CGT and CFDT) and between organised labour and industrial management. Where companies were in financial difficulty, occupation signalled a refusal to leave the premises and to maintain employment (Penissat 2005). Sequestration was rarely an isolated act, but rather a spontaneous act within a wider strategy, from strike to site occupation to management sequestration and, potentially (though rarely), the appropriation of the means of production by the workforce (Sommermeyer, 2008, pp.2829). The CFDT's general support for sequestration (and the CGT's general condemnation of it) took place within a strategic and ideological debate over the mechanisms of transition to socialism (Dubois, 1973, pp.421-6), as the new left progressively adopted autogestion as a central part of socialist renewal in the post-68 phase (Georgi, 2010).

In this light, perhaps the first point to make when considering the current cycle of sequestrations is that, as in previous iterations, it remains a 'means of exercising physical or moral pressure' (Dubois, 1978, p.9), it represents a symbolic reversal of power relations, and it functions to catalyse negotiations and to express worker anger at the perceived injustice of specific plant-level management decisions (Vigna, 2007, pp.105-6). Despite the obvious 
illegality of sequestration, the current cycle is broadly consistent with French traditions of labour conflict resolution, in that it substitutes a political process for an industrial one; it is, in other words, a fundamentally institutionalised process. The non-intervention of the police and absence of effective legal complaints in the private sector is indicative: sequestration is tacitly understood as an industrial process rather than a criminal act, invariably produces the intervention of the industry minister and cabinet, and the search for solutions typically involves the intervention of not just political actors but a panoply of institutional actors and arenas, including the prefect, state prosecutor, state mediator, industrial tribunals, regional labour directorates, the ministry of industry, and so on. It is telling that where the state is directly threatened through the sequestration of public service managers (La Poste on two occasions, the Paris hospitals), the police has intervened effectively and early, and sequestering employees have consistently been prosecuted. In private sector disputes, and despite government condemnation of sequestration, the state has played a different role, that of reducing tensions and enabling negotiation. In an ingenious reading, Hédoin (2009) argues that the non-intervention of law enforcement agencies reflects the willingness of the public authorities to see sequestration as a self-regulating market operation: the rational response of the state is to let companies and employees, through successive iterations, define the correct level of severance terms acceptable to both sides and which will avoid future iterations, with the role of the state to channel both sides towards a constructive, negotiated solution.

Sequestration in the current cycle is thus also integrated into a process; but it is here that the difference between the cycles is palpable. The final stage of the process was once the maintenance of employment, the improvement of working conditions, or the gain of wage increases within an ongoing struggle for social transformation (or, more rarely, under new relationships of power within the plant). In May 1960, for example, workers at the Sambreet-Meuse steelworks in Saint-Brieuc detained two managers overnight in an attempt to improve wages (Béroud \& Mouriaux, 2001, p.150); in April 1971, as a strike over wage increases entered its third week, workers at Egelec-Somarel at Chantepie, on the outskirts of Rennes, detained the company owner and director of personnel in order to force a better wage increase than the 5 centimes an hour currently being proposed; ${ }^{12}$ even in October 1982 , steelworks at Sacilor's Pompey factory sequestered the local manager to ensure union representation on the plant's restructuring committee. ${ }^{13}$

In the current cycle, there is little to suggest that as an action, sequestration forms part of an overall, coordinated, socially transformative strategy, at either plant or national level. Sequestration is of course, simply an action, not an ideology or even a strategy; but what is 
striking is the lack of coordination, the absence of a movement, the vacuum where a transformative project once lay. Despite the criticism and anger at 'des patrons voyous' (hooligan bosses), the goal of sequestrations has been to achieve short-term instrumental gains within the existing social power structure. The form of these gains has been, overwhelmingly, to negotiate a more advantageous severance package than the legal requirement or the management offer. Workers at Scapa reportedly secured the doubling of their severance offer after sequestering four managers; at Caterpillar, management agreed to reduce the number of job losses from 733 to 600, and increase severance terms for those laid off, in return for securing an agreement to greater workforce flexibility; at 3M, workers secured advances on their severance package, and some temporary extensions of posts due to be lost; at Sony, redundancy terms were improved. The effectiveness of sequestration is thus not in doubt; but where previous iterations of sequestration were fundamentally offensive, the current cycle is essentially defensive: at no point and in no cases has sequestration sought a structural transformation of social relations inside or outside the plant. If it is a radical action, then it is explosive rather than planned.

As such, the current cycle of sequestrations is qualitatively different from preceding cycles. Indeed, they suggest much that evokes what Tilly saw as a pre-modern paradigm of patronised and parochial forms of protest (1982, pp.11-17), such as the charivari, and especially, carnival. Sommier (1996, pp.70-2) has already underlined the increasing place of the carnivalesque and the pacification of violence in contemporary labour conflicts, accompanied by the 'ritualisation, theatralisation, and codification' of 'des violences simulacres'; the role of labour representatives becomes one of policing, of ensuring control. Darnton (1985, p.83) tells us that in early modern France, carnival was a moment when

the common people suspended the normal rules of behaviour and ceremoniously reversed the social order or turned it upside down in riotous procession [...] when young people tested social boundaries by limited outbursts of deviance, before being reassimilated in the world of order, submission, and Lentine seriousness.

It is hard not to be struck by two ostensibly contradictory, but in fact complementary, aspects here. The first is that throughout the episodes of sequestration, the reversal of the symbolic order is always temporary and limited. Sequestering employees remain in the position of petitioners, of claimants; what Melucci terms the 'unilateral power of giving, of generating and providing cultural models which constantly reproduces the predominance of the 
apparatuses in complex societies' (1996, p.359) remains unchallenged here, save in the relatively trivial sense of the short-lived control of access to and exit from the premises for specified individuals. The second is the ritual and codified aspect of these actions, and the specific importance of the humiliation of management to their conduct. The anglophone term bossnapping captures this theatrical and even absurd aspect arguably better than the French séquestration, which has overtones of serious criminality. Actions have typically lasted for around twenty-four hours, as if permissible as a day of role reversal before - like the carnival - prevalent social and economic structures of domination re-impose themselves, even within ongoing labour struggles. At this point, carnival typically gives way to the organisation of conflict resolution.

\section{Situating Action in Global Context}

If sequestration is thus a fundamentally symbolic and expressive action, what does it express? Here we have localised instrumental demands, with no formal national organisational structure behind the actions (and, indeed, with union organisations such as the CGT and CFDT attempting in many cases to prevent or minimise them), with few attempts to and little prospect of developing a movement. It would be difficult to talk of the expressive dimension of sequestration as identity building in movement terms, except in the most general (and unrevealing) sense. In our search for an explanation of how sequestration as an action repertoire has mutated across its two most recent cycles of iteration, it makes sense therefore to place these actions within wider structural dynamics.

These dynamics are, of course, recession, deindustrialisation, union reformism, and de-unionisation. But though the conjunctural context of the current cycle of sequestration is acute and (historically) abnormal, there is also a further underlying structural trend here: the closure of profitable concerns by head offices based outside France, and the delocalisation of manufacturing activities based in long-established French plants to countries with lower labour costs. In a globalised system of production and contractualisation, control of the means of production is always elsewhere; the 'factory' as it once was, is now part of an interdependent chain of sites spanning time zones, whose fate is decided in boardrooms outside France. This is a recurring theme in the current cycle: for example, in the BRS action of February 2008, workers sequestered their British manager after discovering that the factory's moulds had been copied and that the operation was, illegally, about to be moved to 
Slovakia. Though the illegality of this particular delocalisation was exceptional, with hindsight it seems a precursor of the events to follow: Sony closed Pontonx-sur-l'Adour in order to shift production to Slovakia; Molex had originally intended to move production to Slovakia, but decided instead to relocate to Nebraska (part of the anger of the Molex workers can be explained by their suspicion that the company had been deliberately misinforming the workers and copying the French moulds); Scapa's French operation had reportedly made profits of over €3 million in 2008; Rohm \& Haas was bought out by Dow Chemicals in April 2009, who announced a restructuring plan to cover the considerable costs of the acquisition, including the closure of the Semoy site, and so on.

The prevalence of sequestration in large industrial concerns, as a way of catalysing negotiations where local managers have relatively little discretionary power, is consistent with the post-1968 sequestrations. But there are also crucial differences. Indeed, a key structural dynamic, especially important in the initial cases in the current cycle, is that of neoliberal globalisation and overt competition between plants within a same transnational group, often located in different national contexts. Giddens identifies the key organizing principle of contemporary globalisation to be deterritorialisation, or "the "lifting out" of social relations from local contexts of interaction and their restructuring across indefinite spans of timespace' (1990, p.21). In the contemporary literature analysing developments in the organisation and repertoires of social movements, this deterritorialisation has predominantly been seen in a positivist light, focusing on the possibilities of constructing counter-hegemonic movements through building networks across borders. On the one hand, accounts focus on the evolution of supra- and international decision-making capacity through the creation of new institutional arenas and their relationships with national norms and power-centres; on the other, there are increasing relational analyses of the development of new protest technologies, transnational actor-networks, and global movements (see inter alia Keck \& Sikkink (1998), Smith \& Johnston (2002), Della Porta \& Tarrow (2005), Della Porta \& Caiani (2009)). Guidry et al conceptualise a developing transnational public sphere, in which 'resources such as organization structures, movement tactics, funds, and personnel flow across borders' (2000, p.9), whilst McDonald traces the effects of globalisation on movement agency and experience, detecting a shift from 'older forms of solidarity to new grammars of fluidarity' within emergent activist subjectivities (2005, p.17).

Analysis of the current cycle of sequestrations opens up a different way of looking at the development of movement repertoires. True, there have been some, highly circumscribed, attempts at internationalising the struggle, with two union representatives from Molex 
visiting the parent company's head office in Chicago, and representatives from Continental visiting workers at plants in Germany. But what strikes the observer most about these particular disputes is the place-bound nature of the exertion of labour power, and the correspondingly uneven battle between the fluidity of capital (and technology) and the lack of mobility of labour. Indeed, the fixity of the industrial workforce recurs frequently in actor accounts of the sequestrations, both in terms of the effects of factory closure on whole communities and in the rooted nature of the workers, especially in plants located in small towns with long-serving workers, sometimes invoking cousins and parents working in the same factories, and the collective social memories generated by these ties. ${ }^{14}$ The references justifying direct action, sometimes from workers who had never before undertaken industrial action, concern not just the direct instrumental benefits of action but also a desire to count, to be seen and be present: 'a symbol of distress', 15 'so as not to die in silence', ${ }^{16}$ even if 'against a multinational, you never win'. ${ }^{17}$

The centrality of narratives of materiality and physical presence in these struggles is striking, and it is useful to make a comparison with recent work by O’Shaughnessy on the importance of corporeality within cinematic representations of the social effects of global capital flows. Addressing the return of a politically committed cinema since the mass public sector strikes of late 1995, O'Shaughnessy argues that there has been a paradigm shift in the mode of appearance of social struggle in French cinema over the last ten years, producing an aesthetic of the fragment. In this analysis, the abandonment of the left, in the face of neoliberalism, of an elaborated politics of class struggle and its associated transformative project, has effectively foreclosed on the representational strategies of collective action familiar to the film form of the committed cinema of a generation ago. The mediating structures (party, union) of a class-based nation state politics are now either absent or subservient to the management of the same transnational capitalism which creates the economic violence from which the protagonists of these films suffer, through oppression, exploitation, and alienation. Struggle, as represented across a comprehensive corpus of recent French films, has become mute, local, and fragmented, lacking the language, organising structures, sense of collective identity and universal claims of class politics. In such circumstances, argues O’Shaughnessy (2007: pp.157-8), what remains is the body, which becomes central to a renascent dramaturgy of resistance, as both site of suffering and, through a melodramatic realism frequently centring on the individual and the family, as starting point for the reconstruction of the social networks and solidarities destroyed by neo-liberal globalisation. 
I'd like to suggest that we should see the actions discussed here in similar light, and place them within the wider context of the emergence of action repertoires in France which stress corporal resistance, such as the spread of civil disobedience, particularly against neoliberal dynamics (Hayes \& Ollitrault, 2012). A similar concern is evident in Siméant’s writing on social movement repertoires, particularly concerning the sans-papiers; actions by unregularised immigrants frequently draw attention to their bodies, either through occupations of specific public spaces or through hunger strikes. This corporeality is important, she argues, because it is one of the few resources wielded by groups whose rights are denied or social status threatened, and is a means of expressing the 'droit à être là', the right to be there (Siméant, 1998, p.287). What I'd like to suggest here is that the sequestration of company bosses should be viewed as an analogous process, along with other forms of action in the recent cycle, such as the hunger strikes staged at Celanese and Madrange. In sequestrations, it is not just the bodies of managers and directors that are engaged through the restrictions imposed upon them, but those also of the workers staging the action, as they express their right to continue to exist in their own space of labour, their right à être là, and for their status to be recognised. Penissat (2005, p.84) suggests that, in the post-1968 wave of industrial conflict, factory occupations represented a politicisation of the workplace through the symbolic affirmation of physical presence, in contrast with the strike's abandonment of the workspace for the national political space. If, for Shorter and Tilly (1974, pp.343-4), one of the key functions of the strike is the creation of a 'public drama', exerting and maintaining pressure on the political centre in order to produce political transformation, then sequestering the boss is a public melodrama: a physical display demonstrating symbolic power, creating a spectacular media event, constraining the intervention of the public authorities, but without creating a relay to the political centre or being integrated into an explicit transformative political project. It is a tactic to produce direct instrumental gains, and a symbolic affirmation of collective, physical presence in the face of the dematerialised global economy; as such, it is also an affirmation of local solidarities and collective material consciousness.

\section{Conclusion}

Why a wave of sequestrations should take place in France in 2009-10 is in many ways explicable through standard social movement theory. Grievances are sudden and abnormally high; there is a strong sectoral and national cultural repertoire of direct action; very low unionisation in the private sector in France effectively makes classical labour movement 
activism difficult; mediatisation is fundamental to the expression of grievances, and is an obvious mechanism of rapid diffusion of a modular, transferable protest form; state responses are of accommodation rather than repression. The overall effect is one of amplification, and the nationalisation of a specific form of action into a wider explanatory narrative of national cultural forms of social mobilisation. In common with previous cycles of sequestration in France, these actions are largely symbolic displays aiming to create favourable outcomes. But, in contrast with previous cycles, they are no longer integrated into a narrative of potential social transformation, and testify to a relative conservatism in their instrumental goals: no longer even the maintenance of employment, but rather, simply, a more handsome pay-off than the one proposed.

But these actions also raise questions of our way of understanding the effects of globalisation on social mobilisation. Beck and Sznaider have recently called for the development of a research agenda focusing on 'a new cosmopolitan social and political science', which they oppose to the 'retrogressive idealism of the national perspective in politics, research and theory', as the 'dualities of the global and the local, the national and the international, us and them, have dissolved and merged together in new forms that require conceptual and empirical analysis' (2006, p.22, p.6, p.3). What is striking about their thesis is its neglect of the relationships of power that structure these dualities. The problem, as Burawoy (2000, p.337-9) notes, is that most people’s experiences of globalisation aren’t those of the cosmopolitan elite. The incidents of sequestration are a series of hot-spots which make these imbalances manifest: on one side of the scale, the fluidity of capital and resources (and some personnel) across a 'flat earth' (as neo-critical geographers such as Friedman (2005) might put it); on the other, even in a 'global winner' country like France, there is fixity, and geographical, social, and material hierarchies.

Even as 'bossnapping' is seen as ‘typically French', the change in the goals of sequestration compared with previous cycles of iteration suggests the effects of neo-liberal globalisation on the capacity of social actors to aggregate grievances at the national scale, whilst the simultaneously symbolic and instrumental nature of the action suggests that we need to revisit the link between expressivity and collective identity. The expressive dimension of sequestration - alongside, perhaps, forms of civil disobedience and hunger strikes, both of which have been prevalent in France since the late 1990s - points to the emergence of a direct, physical form of protest, responding to profound epochal mutations in the structures of capitalism and the state, specifically the deterritorialisation and dematerialisation dynamics of neo-liberal globalisation and diffusion of power away from the 
central state institutions; and point also to the development of a melodramatic politics of presence. Foremost amongst the questions that this raises is whether this return to localism represents an admission of defeat, a cry of despair, and the mere salvaging of compensation for the loss of transformative potential; or whether it constitutes the first steps in a new radicalism, a blueprint for a direct action, for the re-statement of fixity and place in relations within civic society - for a politics of presence and of proximity - in the face of the perpetual absence at the heart of transnational capital flows.

\section{References}

Adam, G. \& J-D. Reynaud (1978) Conflits du travail et changement social, Presses Universitaires de France, Paris.

Beck, U. \& N. Sznaider (2006) 'Unpacking Cosmopolitanism for the Social Sciences: A Research Agenda', British Journal of Sociology, vol. 57, no. 1, pp. 1-23.

Béroud, S. (2010) 'Violence et radicalité dans les conflits du travail: quelques pistes d'analyse', in Violences et société. Regards sociologiques, eds A. Ndiaye \& D. FerrandBechmann, Desclée de Brouwer, Paris.

Béroud, S. \& R. Mouriaux (2001) 'Violence et sabotage dans les grèves en France’, in

Cellatex ; quand l'acide a coulé, C. Larose, S. Béroud, R. Mouriaux \& M. Rabhi, Syllepse, Paris.

Burawoy, M. (2000) ‘Grounding Globalization’, in Global Ethnography: Forces, Connections, and Imaginations in a Postmodern World, eds M. Burawoy, J. A. Blum, S. George, Z. Gille, T. Gowan, L. Haney, M. Klawiter, S. H. Lopez, S. Ó’Riain, \& M. Thayer, University of California Press, Berkeley \& London.

DARES (2010) 'Emploi, chômage, population active : bilan de l'année 2009', DARES

Analyses, no. 50, http://www.travail-solidarite.gouv.fr/IMG/pdf/2010-050__Emploi_chomage_population_active_-_bilan_de_l_annee_2009.pdf

Darnton, R. (1985) The Great Cat Massacre and other Episodes in French Cultural History, Vintage, New York.

Della Porta, D. \& M. Caiani (2009) Social Movements and Europeanization, Oxford University Press, Oxford. 
Della Porta, D. \& S. Tarrow (eds) (2005) Transnational Protest \& Global Activism, Rowman \& Littlefield, Boston.

Downs, A. (1972) 'Up and down with Ecology - The "Issue-Attention Cycle” ', Public Interest, vol. 28, pp. 38-50.

Dubois, P. (1973) 'La Séquestration’, Sociologie du Travail, vol. 15, no. 4, pp. 410-27.

Dubois, P. (1978) 'New Forms of Industrial Conflict: 1960-1974', in The Resurgence of Class Conflict in Western Europe since 1968, vol. 2, eds C. Crouch \& A. Pizzorno, MacMillan, London.

Ducros, C. \& J-Y. Guérin (2010) Le Management de la colère, Max Milo, Paris.

Friedman, T. (2005) The World is Flat. A Brief History of the Twenty-First Century, Farrar, Straus \& Giroux, New York.

Gamson, W. (1990) The Strategy of Social Protest, $2^{\text {nd }}$ edn, Wadsworth, Belmont, California.

Georgi, F. (2010) 'L’Autogestion, utopie libertaire ou utopie libérale ?’, in 1968 entre libération et libéralisation. La grande bifurcation, eds M. Margariaz \& D. Tartakowsky, Presses Universitaires de Rennes, Rennes.

Giddens, A. (1990) The Consequences of Modernity, Cambridge University Press, Cambridge.

Guidry, J. A., Kennedy, M. D. \& M. N. Zald (2000) 'Globalizations and Social Movements', in Globalizations and Social Movements. Culture, Power and the Transnational Public Sphere, eds J. A. Guidry, M. D. Kennedy \& M. N. Zald, Ann Arbor, University of Michigan Press.

Hayes, G. \& S. Ollitrault (2012), La Désobéissance civile, Presses de SciencesPo, Paris.

Hédoin, C. (2009) Théorie de la séquestration de patrons, http://eco.rue89.com/2009/04/12/theorie-de-la-sequestration-de-patrons (accessed 18 March 2010).

Jacquier, J-P. (2008) L’Introuvable Dialogue social, Presses Universitaires de Rennes, Rennes.

Keck, M. \& K. Sikkink (1998) Activists beyond Borders. Advocacy Networks in International Politics, Cornell University Press, Ithaca \& London. 
Kolins Givan, R., Roberts, K. M. \& S. A. Soule (2010) 'Introduction: The Dimensions of Diffusion', in The Diffusion of Social Movements: Actors, Mechanisms, and Political Effects, eds R. Kolins Givan, K. M Roberts \& S. A. Soule, Cambridge University Press, Cambridge.

Larose, C., Béroud, S., Mouriaux, R. \& M. Rabhi (2001) Cellatex : quand l'acide a coulé, Syllepse, Paris.

McDonald, K. (2005) Global Movements: Action \& Culture, Blackwell, Oxford.

Melucci, A. (1996) Challenging Codes. Collective Action in the Information Age, Cambridge University Press, Cambridge.

O’Shaughnessy, M. (2007) The New Face of Political Cinema. Commitment in French Film since 1995, Berghahn, Oxford.

Penissat, E. (2005) 'Les Occupations de locaux dans les années 1960-1970 : Processus sociohistoriques de « réinvention » d'un mode d'action', Genèses, no. 59, pp. 71-93.

Shorter, E. \& C. Tilly (1974) Strikes in France 1830-1968, Cambridge University Press, London \& New York.

Siméant, J. (1998) La Cause des sans-papiers, Presses de la FNSP, Paris.

Smith, J. \& H. Johnston (eds) (2002) Globalization and Resistance. Transnational Dimensions of Social Movements, Rowman \& Littlefield, Boston.

Sommermeyer, P. (2008) ‘Sous les pavés, la grève’, Réfractions, no. 20, pp. 27-35.

Sommier, I. (1996) 'La Dialectique violence physique / violences symboliques. L'Exemple de la violence ouvrière dans les années 68', in La Gouvernabilité, ed. CURAPP, Presses Universitaires de France, Paris.

Tarrow, S. (1998) Power in Movement. Social Movements and Contentious Politics, $2^{\text {nd }}$ edn, Cambridge University Press, Cambridge.

Tilly, C. (1982) European Violence and Collective Action since 1700, Center for Research on Social Organization Working Paper, no. 277, University of Michigan, Michigan.

Tilly, C. (1984) 'Social Movements and National Politics’, in Statemaking and Social Movements. Essays in History and Theory, eds C. Bright \& S. Harding, University of Michigan Press, Ann Arbor. 
Vigna, X. (2007) L'Insubordination ouvrière dans les années 68. Essai d'histoire politique des usines, Presses Universitaires de Rennes, Rennes.

\footnotetext{
1 'Three British bosses held hostage for 18 hours by militant workers at factory in France', Daily Mail, 8 April 2009.

2 'Sure, kidnap the man', Newsweek, 25 April 2009.

${ }^{3}$ Agnès Poirier, 'France's theatre of redundancy', The Guardian, 17 July 2009.

4 ، « La séquestration de patrons est typiquement française »', Libération, 1 April 2009

5 'Mouvements radicaux : «Peu de chances de généralisation»', Le Figaro, 30 July 2009.

${ }^{6}$ See Ducros \& Guérin (2010, pp.64-8) for a lively discussion of the absence of legal procedures in the private sector. Note that this is not the case where this has happened in the public sector, where the public and court authorities have intervened rapidly. This includes the suspended fines handed down to eleven postal workers, including Olivier Besancenot, for the supposed sequestration of thirteen management employees in a postal workers' dispute in Nanterre in May 2010. At the time of writing, this sentence is under appeal.

7 'Après un licenciement économique', La Croix, 12 August 2010.

8 'Séquestration de patrons: mode d'emploi', 20 Minutes, 2 March 2010 ; see also Parise in 'L’art de la guerre', Le Nouvel Economiste, 11 June 2009.

9 'Tous unis autour des New Fabris', Libération, 31 July 2009.

10 'Les salariés de PTPM se fâchent', L'Humanité, 28 April 2010.

11 'Nortel : « Nous ne sommes pas des terroristes »', Le Monde, 15 July 2009.

12 'Grève à l'usine Egelec-Somarel', Bretagne Actualités, 20 April 1971, see

http://www.ina.fr/economie-et-societe/vie-sociale/video/RXF01017627/greve-a-l-usineegelec-somarel.fr.html

13 'Le directeur de l'usine Pompey sequestré', Lorraine soir, 28 October 1982, see http://www.ina.fr/economie-et-societe/vie-sociale/video/SXC02011685/le-directeur-de-lusine-pompey-sequestre.fr.html

${ }^{14}$ See for example 'Silence des machines, paroles des ouvriers', Libération, 30 July 2009.

15 'Nortel : « Nous ne sommes pas des terroristes »', Le Monde, 15 July 2009.

16 'A Châtellerault, le désarroi et la révolte', Libération, 14 July 2009.

17 ‘Tonneins. Les JLG ont obtenu 30000 €’, La Dépêche du Midi, 18 July 2009.
} 